\title{
FINANCIAL INCLUSION IN THE CONTEXT OF SUSTAINABLE DEVELOPMENT OF RURAL AREAS
}

\author{
Iryna Abramova ${ }^{1}$, Larysa Nedilska ${ }^{2}$, Nataliia Kurovska ${ }^{3}$, Halyna Martynyuk ${ }^{4}$ \\ ${ }^{1}$ Assoc. Prof. Dr. Polissia National University, Old Boulevard 7, Zhytomyr, Zhytomyr region, 10008, Ukraine. \\ Phone No.+380968766380. E-mail address: irina79abramova@gmail.com \\ ${ }^{2}$ Assoc. Prof. Dr. Polissia National University, Old Boulevard 7, Zhytomyr, Zhytomyr region, 10008, Ukraine. \\ E-mail address: lorka_nedelskaya@ukr.net \\ ${ }^{3}$ Assoc. Prof. Dr. Polissia National University, Old Boulevard 7, Zhytomyr, Zhytomyr region, 10008, Ukraine. \\ E-mail address: kurovska@gmail.com
}

${ }^{4}$ PhD Polissia National University, Old Boulevard 7, Zhytomyr, Zhytomyr region, 10008, Ukraine. E-mail address: g.martinyuk66@gmail.com

Received 2807 2021; Accepted 05082021

\begin{abstract}
Financial inclusion is a means to make full use of financial services, which stimulates the introduction of innovation, mobilization of savings and investment support, and thus contributes to the economic development of territories. The purpose of the study is to substantiate scientific and practical approaches to determining the role and place of financial inclusion in sustainable development of rural areas. The state of financial inclusion in rural areas has been assessed having applied the statistical-economic and calculation-constructive methods. The abstract-logical method made it possible to prove the positive impact of financial inclusion on the sustainable development of rural areas and to offer proposals for its further advancement. It has been argued that the key tasks of financial inclusion in the context of sustainable development of rural areas are financial education, access to financial services, and protection of the rights of consumers of financial services.
\end{abstract}

Key words: financial education, financial inclusion, financial literacy, financial service, payment infrastructure, rural areas, rural development.

JEL Codes: G2, R1, O1.

\section{Introduction}

According to the World Bank Group (WBG), until 2014, about 2 billion adults in the world had not used financial services. At the same time, the experience of developed economies shows that creation of the conditions for free access of various segments of the population to financial services increases their income, reduces the social burden on the state budget, stimulates domestic investment and has a positive impact on the country's economy. In cooperation with WBG, global financial institutions have set a goal to make financial services available to adults worldwide by 2020 .

In Ukraine, according to WBG, in 2017 only $63 \%$ of the adult population had at least one account in a financial institution; in rural areas this figure was $55 \%$. When it comes to other financial services, the situation is even worse. According to a research by the U.S. Agency for International Development (USAID) conducted within the framework of the project Financial Sector Transformation, in 2018 only $46.3 \%$ of the rural population over

Copyright (C 2021 Author(s), published by Vytautas Magnus University. This is an open access article distributed under the terms of the Creative Commons Attribution Non-Commercial 4.0 (CC BY-NC 4.0) license, which permits unrestricted use, distribution, and reproduction in any medium provided the original author and source are credited. The material cannot be used for commercial purposes. 
the age of 15 took loans, about $12 \%$ had savings and less than $0,05 \%$ made investments. The key reasons for this situation are low incomes of the rural population, lack of awareness about financial services, lack of financial institutions in rural areas, lack of trust in financial intermediaries and lack of a reliable system of protection of the rights of consumers of financial services.

The problems of financial inclusion are addressed by the world leading scholars. Allen, Franklin, Demirguc-Kunt, Asli, Klapper, Leora and Martinez Peria, Maria (2016) believe that financial inclusion can bring many welfare benefits to individuals. M. Mostak Ahamed and Sushanta Mallick (2019) find that higher level of financial inclusion contributes to greater bank stability. Efosa Ojomo (2019) say "The incessant quest to achieve financial inclusion - often measured by number of bank accounts open - for the almost two billion people who currently lack access is futile, so long as people remain trapped in a cycle of poverty and low productivity". Peterson K. Ozili (2020) examines various conditions for optimality in financial inclusion. Rodney Hood (2020) pointed out the impact international regulations can have on financial inclusion - and why WOCCU advocates for the fair and proportional treatment of credit unions in front of international standard setting bodies, such as the Basel Committee on Banking Supervision.

L. Dijkstra and H. Pullman's (2014) research is focused on support for rural development. The researchers propose to employ new approaches to the classification of urban and rural areas, which, in their opinion, will contribute to a more transparent and efficient allocation costs for their maintenance. L. Domeova and A. Dzhyndrova (2014) highlight the tools that can improve the quality of life in rural areas. M. Altman (2015) believes that agricultural service cooperatives are a key driving force that can positively influence sustainable rural development.

Ukrainian scholars also make a significant contribution to the development of financial inclusion. In particular, Lutsiv (2018) focuses on theoretical approaches to understanding the essence of an inclusive model of economic development under present-day conditions and its organic component - financial inclusion, as well as specific practical aspects of the NBU Strategy aimed at the strengthening of financial inclusion. T. Zinchuk, N. Kutsmus, O. Kovalchuk (2018) believe that the prerequisites for sustainable development of the rural economy in Ukraine are its multifunctionality and inclusiveness. O. Vernei (2019) deals with the economic content of financial inclusion as an indicator of the accessibility of financial services to the population, and also identifies modern approaches to its measurement. Yu. Shapoval and O. Yukhta (2019) argue that "Financial inclusion is a means of "full-fledged" use of the tools of the financial services industry, which ultimately contributes to long-term economic growth, as it stimulates innovation, mobilization of savings and investment support".

K. Anufriieva and A. Shkliar (2019) established that financial inclusion is one of the factors for economic development; the study of the role of financial inclusion among the factors for socioeconomic development was substantiated in our previous studies (Abramova, 2020) was proved that low incomes of the population, limited access to financial services, underdevelopment of payment infrastructure, low level of financial education and financial literacy of Ukrainians are the key reasons for the slow development of financial inclusion in Ukraine. O. Borodina, I. Prokopa, S. Kyryziuk and V. Yarovyi (2020) insist on the need to create a Rural Development Fund. Its funds would be allocated to the development of rural infrastructure, accessibility of medical and educational services in rural areas, support for small agricultural producers, etc.

The current model of rural development in Ukraine has been formed under the influence of various negative socioeconomic, political and legal factors. As a result, the rural economy, which, given its natural resource potential, could become the driver of the entire economic system of the state, has become its raw material appendage. Workers engaged in agricultural production receive the lowest 
wage among European countries, averaging EUR 130 per month. The rural population is steadily declining, which can be accounted for by the natural aging of the population, low birth rate, and labor migration. Rural economic entities have not been able to establish cooperation, to coordinate or consolidate their efforts in order to achieve sustainable development.

In our previous studies (Abramova, Nedilska, Dema, 2018), we outlined that "the prospects for rural development are related to the solution of the following tasks: the ability of territorial communities to assess and effectively use their own financial opportunities for economic, social and environmental progress; search for alternative sources of funding; transparency of the processes of receiving and using budget funds; establishing the relationship between the state authorities and farmers, who are end users of financial resources; tightened control over the use of budget funds; the ability to involve business entities in addressing the acute economic, social and environmental issues in rural areas; formation of investment image of rural settlements and investment development of small and medium-sized agricultural producers". At the same time, despite the fact that a significant amount of research on both financial inclusion and rural development progress has been done, the issue of financial inclusion in the context of sustainable development of rural areas has been insufficiently studied and reflected in the literature. In this regard, we consider the topic of the study relevant and timely.

\section{Objectives and methods}

The hypothesis of the current study is that financial inclusion will contribute to the sustainable development of rural areas.

The purpose of the study is to substantiate scientific and practical approaches to determining the role and place of financial inclusion in the sustainable development of rural areas.
The objectives of the study are as follows: to provide theoretical substantiation to the role and place of financial inclusion in the development of rural areas; to assess the state of financial inclusion in rural areas; to prove the positive impact of financial inclusion on the development of rural areas.

The object of the study is the process of financial inclusion in rural areas. The subject of the study is a set of theoretical, methodological, scientific and applied provisions for financial inclusion in rural areas.

The study was carried out according to the general methodological scheme of the system approach based on data from the World Bank, the National Bank of Ukraine, the State Statistics Committee, the USAID project "Financial Sector Transformation", etc. The novelty of this approach consists in a comprehensive and staged assessment of the state of financial inclusion in rural areas, as well as the development of tools that are able provide a positive impact on improving the level and quality of life in rural areas and sustainable development of rural areas.

The following methods of economic research were used to solve the objectives: the method of comparative analysis (to determine the state of financial inclusion in rural and urban settlements based on the adaptation of foreign experience of financial inclusion in rural areas); the empirical method (to determine the state of financial inclusion in rural settlements according to the analytical data of the past 10 years); the abstract-logical method (made it possible to prove the positive impact of financial inclusion on the sustainable development of rural areas and to formulate proposals for its further progress).

\section{Research results and discussion}

Ukraine has significant natural resource potential for the development of rural areas. At the same time, a significant part of Ukrainian villages are in a very neglected state; and more than 500 of them have completely disappeared from the map of the country during the years of independence (according to the Institute for 
Demography and Social Studies of the National Academy of Sciences of Ukraine). The reasons for this are ambiguous. On the one hand, the output of agricultural production is increasing; there are great opportunities to export agricultural products. However, the rural economy unfortunately remains unable to create enough jobs for the rural population and provide it with sufficient income. The rural economy cannot also self-finance infrastructure development or promote the formation of social and environmental balance in rural areas. As a result, the rural population, especially young people, migrates to larger settlements or abroad, where there are sources of income, decent working and living conditions. The rural population is constantly declining, and the rural infrastructure is deteriorating.

The experience developed economies shows that the financial inclusion of the rural population contributes to increasing its welfare, reducing social inequality between rural and urban residents, economic growth of rural areas. The integration of Ukrainian rural residents into the financial services market is rather slow. According to the World Bank, as of the end of 2019, only $59 \%$ of rural residents had at least one bank account (Fig. 1).

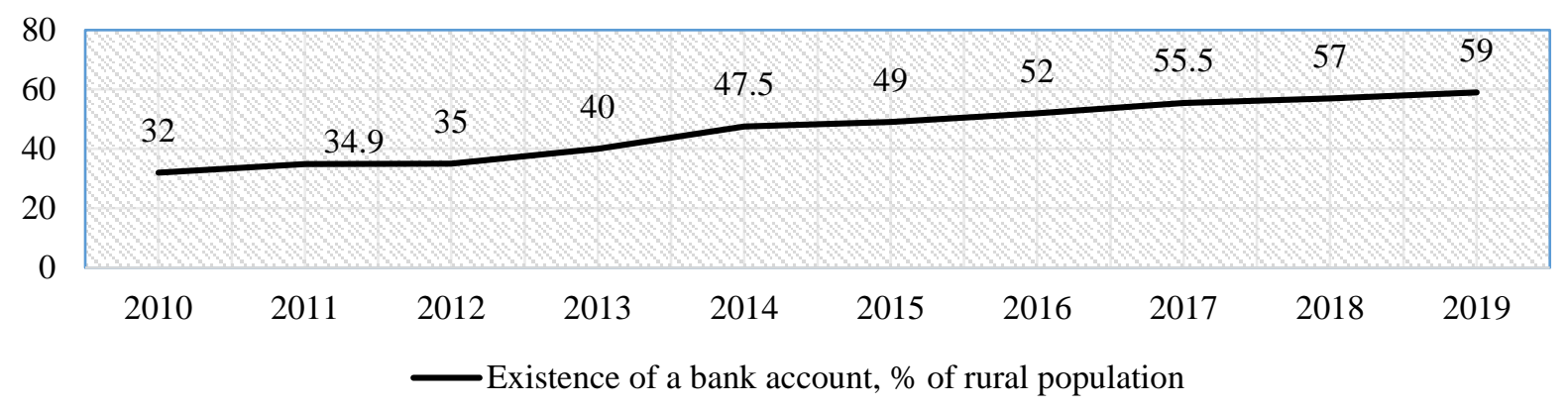

Figure 1. Share of rural population who have at least one bank account, \% *Source: The World Bank Group (2021)

According to the survey report "Financial Literacy, Awareness and Inclusion in Ukraine" (2017), which was prepared by the Partners for Financial Stability project and InMind in cooperation with the U. S. Agency for International Development (USAID), the rural population in Ukraine is less interested in finance than the urban population and shows a more biased and negative attitude towards financial services.

Analysis of recent research and publications has shown that financial inclusion is commonly considered in three areas: financial literacy, accessibility to financial services, and protection of the rights of consumers of financial services. Financial literacy denotes the level of knowledge and skills of the population, as well as information about their rights and responsibilities in the field of financial services. A survey conducted by the Partners for Financial Stability project showed that $47.5 \%$ of rural residents consider their knowledge of financial literacy to be satisfactory, $23.2 \%$ unsatisfactory, $7.6 \%$ do not know anything and only $16.1 \%$ find their level of financial literacy to be good, and $2.1 \%$ excellent. At the same time, a test in financial mathematics showed that $43.8 \%$ of the rural residents have unsatisfactory knowledge, $20.2 \%$ satisfactory, $14.6 \%$ do not know anything at all and only $21.4 \%$ have a deep understanding of finance.

It has also been found that only $8 \%$ of rural residents keep track of their income and expenses, more than $50 \%$ have only a general idea of the income and expenses in their own households. Another $25 \%$ of Ukrainian rural residents spend all their money on daily needs and do not keep track of expenses. What's interesting is that most of those who do not budget do not have savings and estimate their financial situation below average.

At the same time, better financial awareness encourages the population to carry out financial planning, transform free funds into investments, and seek new financial 
programs and products. We believe that due to insufficient financial literacy, consumers cannot make rational decisions on the use of their own financial resources. As a result, they avoid transactions to invest or attract funds or carry out risky transactions.

Another important aspect of financial inclusion in rural areas is the accessibility to financial services. The problem of insufficient development or physical lack of financial infrastructure in rural areas remains relevant. Currently, Ukrposhta is virtually the only operator that works even in remote parts of Ukraine providing a number of financial services, including payment for utilities and other services, remittances, payment of pensions and various types of social assistance. For many rural residents Ukrposhta's post offices remain the most important component of FinTech, the market of domestic financial technologies, the development of which has been approved by the National Bank of Ukraine in the Strategy on FinTech Development in Ukraine until 2025. According to the World Bank, the dynamics of the volume of services provided in the field of telecommunications and postal services in rural areas during 2010-2017 shows a downward trend (Fig. 2).

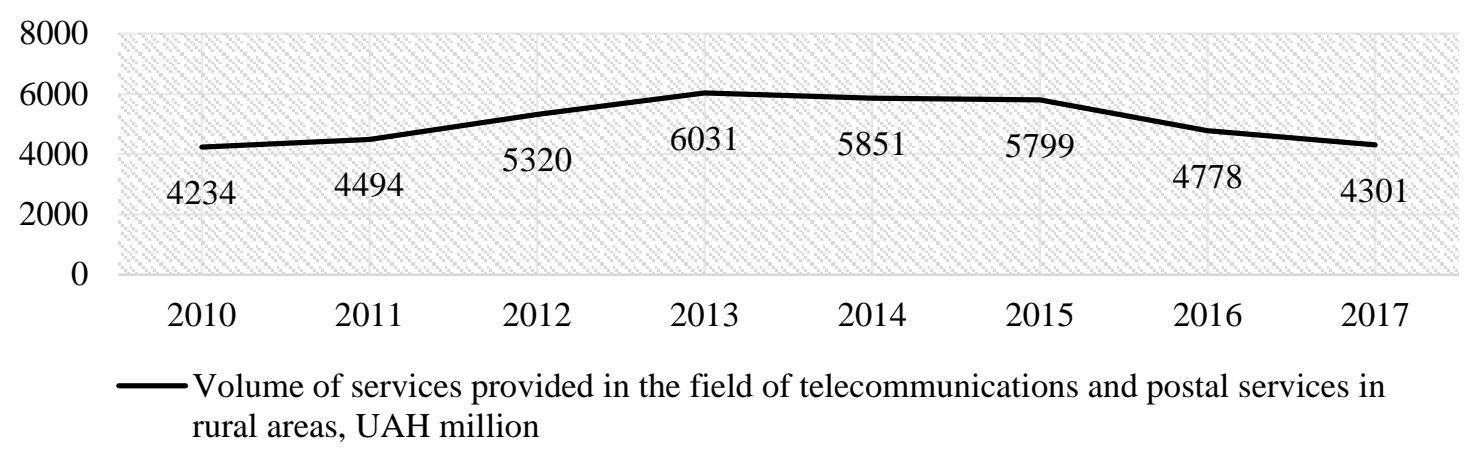

Figure 2. Dynamics of the volume of services provided in the field of telecommunications *Source: The World Bank Group (2021) and postal services in rural areas, UAH million

As for the activities of banking institutions, they have set a course for the optimization of the network of their branches while developing online services at the same time. The optimization primarily affected branches in rural areas with a small number of residents. In particular, for several years running, the two state-owned banks Oschadbank and Privatbank have been reducing the number of their branches. They justify their actions by the economic inexpediency of maintaining such structural subdivisions, as well as the "trend towards digitalization".

The accessibility to financial inclusion is also ensured through the development of payment infrastructure, including a network of contactless terminals, terminals in trade and service networks, other devices, the electronic money market, electronic payment systems and more. According to the World Bank, the number of bank branches and ATMs per 100,000 adults tends to decrease (Fig. 3). 


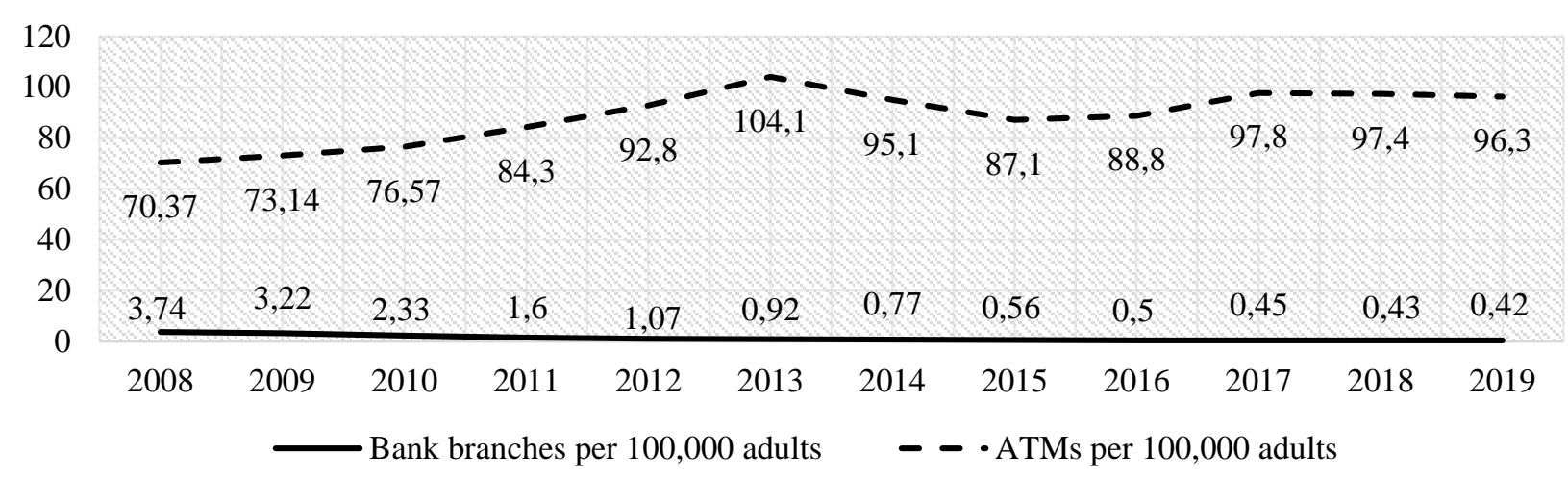

Figure 3. Dynamics in the number of bank branches and ATMs per 100,000 adults, units *Source: The World Bank Group (2021)

The fact that banks initiate the development of remote and online financial services is certainly a positive phenomenon. At the same time, it should be taken into account that the use of online financial services by rural residents is also currently limited due to the low level of connection of individual users to the Internet. According to the National Commission for State Regulation of Communications and Informatization, at the beginning of 2020 7,265,000 Internet access points were registered in Ukraine, of which only $1,173,000$ were in rural areas, which is more than 7 times less than in the rest of the country. In cities with a population of over 100,000 people the share of Internet users was $74 \%$, while in the villages it varied from $53 \%$ to $58 \%$. In addition, young people are more integrated into the World Wide Web and know how to use various Internet applications, whereas the majority of the elderly do not have such knowledge and skills. In this respect, the issues of not only financial, but also digital literacy are becoming especially relevant.

Qualitative progress of financial inclusion involves not only the development of financial literacy and accessibility to financial services, but also the creation of effective mechanisms to protect the rights of consumers of financial services. Ukraine is a country whose population has repeatedly experienced the impact of financial and economic crises, the devaluation of the currency, and inflation processes. Older people have lost their savings not once due to the unreliability of the financial and banking system. As a result, Ukrainians have formed distrust of financial institutions and the national currency. Citizens feel insecure due to the lack of legal instruments to regulate the rights of consumers of financial services. The Strategy on FinTech Development in Ukraine until 2025 outlines the vision of the NBU in resolving these issues. The vision of the strategy is based on Ukraine's aspirations towards European integration, which envisage, among other things, the formation of a reliable system of protection of the rights of consumers of financial services.

The analysis of the state of financial inclusion in rural areas made it possible to single out key objectives, tools for their implementation, as well as the expected outcomes in the context of sustainable development of rural areas (Table 1). 
Table 1. Key objectives of financial inclusion, tools for their implementation, and the expected outcomes in the context of sustainable development of rural areas

\begin{tabular}{|c|c|c|}
\hline Objectives & Tools for implementation & Expected outcomes \\
\hline $\begin{array}{l}\text { Financial } \\
\text { education }\end{array}$ & $\begin{array}{l}\text { - continuing the development of educational } \\
\text { programs aimed at improving the financial } \\
\text { literacy of rural residents; } \\
\text { - online training on financial literacy; } \\
\text { - workshops, lectures, conferences dedicated to } \\
\text { improving the financial literacy of the rural } \\
\text { population; } \\
\text { - forming a culture of non-cash and online } \\
\text { payments among rural residents. }\end{array}$ & $\begin{array}{l}\text { - better awareness of rural residents in } \\
\text { financial matters; } \\
\text { - budgeting of household incomes and } \\
\text { expenses; } \\
\text { - growth in incomes of rural population; } \\
\text { - encouraging the transformation of } \\
\text { savings into investment; } \\
\text { - economic progress of rural areas. }\end{array}$ \\
\hline $\begin{array}{l}\text { Accessibility to } \\
\text { financial services }\end{array}$ & $\begin{array}{l}\text { - development of financial infrastructure in rural } \\
\text { areas; } \\
\text { - adaptation of financial products / services and to } \\
\text { international quality standards; } \\
\text { - exchange of information on financial services; } \\
\text { - application of modern IT technologies while } \\
\text { working with clients; } \\
\text { - development of digital financial services. }\end{array}$ & $\begin{array}{l}\text { - expanding the range of financial services } \\
\text { in rural areas; } \\
\text { - improving the quality of financial } \\
\text { services in rural areas; } \\
\text { - infrastructure development of rural areas; } \\
\text { - inclusion of rural population in the } \\
\text { financial system. }\end{array}$ \\
\hline $\begin{array}{l}\text { Protecting the } \\
\text { rights of } \\
\text { consumers of } \\
\text { financial services }\end{array}$ & $\begin{array}{l}\text { - improvement of legislation on the protection of } \\
\text { the rights of consumers of financial services; } \\
\text { - forming a system of state guarantees to } \\
\text { consumers of financial services. }\end{array}$ & $\begin{array}{l}\text { - stabilization of the financial and banking } \\
\text { system; } \\
\text { - intensified monitoring and control over } \\
\text { the activities of financial institutions; } \\
\text { - increased confidence of the rural } \\
\text { population in financial institutions. }\end{array}$ \\
\hline
\end{tabular}

*Source: own research

USAID research shows that the level of development of territories directly depends on the income of the population residing in these territories. In turn, citizens' incomes depend on their behavior and attitude to money: how they plan their expenses, whether they make savings, whether they use loans to meet current needs. That is why financial education, as the basis of financial literacy, is a driving force that can positively affect the financial wellbeing of citizens, encourage them to manage their own finances and expand financial opportunities. Also, we should not forget that we live in the age of digital technologies, so it will be helpful to use digital tools to improve financial literacy, such as interactive educational programs, online financial games. It is important to emphasize the development of digital financial services as one of the components of an inclusive financial system. The accessibility to financial services in rural areas will increase the degree of interaction between rural residents and the financial system. The formation of an effective system of protection of the rights of consumers of financial services will increase the confidence of rural residents in financial institutions, which in turn will facilitate their smooth interaction with the financial space.

\section{Conclusions}

It has been established that the state of financial inclusion in Ukraine has not developed properly. Only $59 \%$ of rural residents have at least one bank account, $43.8 \%$ have unsatisfactory knowledge in financial matters, and $25 \%$ of Ukrainian rural residents spend all their money on daily needs and do not keep track of their expenses. This is explained by low incomes of rural population (on average less than EUR 130 per month), limited access to financial services due to insufficient development of payment infrastructure, low level of financial education and financial literacy. At the same time, the world experience shows that the creation of conditions for free access of all segments of the 
population to financial products and services contributes to economic development and income growth by means of improving the efficiency of asset management, simplification of investment mechanisms, availability of financial intermediaries. Prospects for the development of financial inclusion are related to the creation of effective mechanisms to protect the rights of consumers of financial services, conditions for improving financial literacy and awareness of services that banking and non-banking financial institutions provide, and to the development of payment infrastructure and digital technologies in the financial sector.

It has been proved that the key objectives of financial inclusion in the context of sustainable development of rural areas are financial education, accessibility to financial services and protection of the rights of consumers of financial services. It has been substantiated that better awareness of rural residents on financial issues will enable them to budget the income and expenses of their own households, will encourage the transformation of savings into investment, which in turn will lead to increased incomes of rural population and economic development of rural areas. Expanding the range and quality of financial services in rural areas will contribute to the infrastructural development of rural areas and the inclusion of the rural population in the financial system. The formation of an effective system of protection of the rights of consumers of financial services can restore the confidence of the rural population in financial institutions, which, together with other measures, will contribute to achieving social equilibrium and sustainable development of rural areas.
The implementation of the proposed measures will contribute to the sustainable development of rural areas through the use of economic potential inherent in financial inclusion. As a result, it is expected that the incomes of rural population will increase and there will be an upswing in the rural economy, the level and quality of life in rural areas will improve, the ecological balance will be maintained, rural areas will be preserved and improved, their infrastructure will be developed.

The authors specify the role and place of financial inclusion in the development of rural areas; the state of financial inclusion in rural areas has been assessed; the positive influence of financial inclusion on the development of rural areas has been proved; the key tasks of financial inclusion, as well as tools for their implementation and expected outcomes in the context of sustainable development of rural areas have been identified.

This work was carried out on the basis of the Polissia National University, commissioned by the Ministry of Education and Science of Ukraine, within the framework of scientific research topics: "Financial Instruments of Rural Development in the Conditions of Uncertainty", state registration number 0216u109312. Cover Letter dated March 05, 2021. The results of the study will be presented for use by (1) the Ministry of Agrarian Policy and Food of Ukraine (which is interested in improving the social and economic situation in rural areas); (2) local authorities (concerned about the development of rural areas); (3) residents of rural areas (willing to improve their living conditions).

\section{References}

The World Bank Group (2021). Global Financial Inclusion. https://databank.worldbank.org/reports.aspx?source=global-financial-inclusion [2021 0204$]$.

USAID. Financial Sector Transformation Project (2019). Financial Literacy, Financial Inclusion And Financial Well-Being In Ukraine. - http://surl.li/sbgy [2021 21 04].

Allen, F., Demirguc-Kunt, A., Klapper, L., Martinez Peria, M. (2016). The foundations of financial inclusion: Understanding ownership and use of formal accounts // Journal of Financial Intermediation. Vol. 27: 1-30. http://surl.li/aaybx

Mostak Ahamed, M., Mallick, S. (2019). Is financial inclusion good for bank stability? International evidence // $\begin{array}{llllllll}\text { Journal of Economic Behavior \& } & \text { Organization. Vol } 157 & \text { (C): } 403-427 . & -\end{array}$ http://www.sciencedirect.com/science/article/pii/S0167268117302056. 


\section{Management Theory and Studies for Rural Business and Infrastructure Development eISSN 2345-0355. 2021. Vol. 43. No. 3: 328-336 \\ Article DOI: https://doi.org/10.15544/mts.2021.29}

Efosa, O. (2019). Chasing financial inclusion is a red herring - economic inclusion should be the goal. http://surl.li/aaybp [2021 2104$]$.

Ozili, P. K. (2020). Optimal Financial Inclusion. In Jeon, B. N., Wu, J. (Eds.). Emerging Market Finance: New Challenges and Opportunities (Vol. 21) (pp. 251-260). Bingley: Emerald Publishing Limited. https://doi.org/10.1108/S1569-376720200000021014.

Dijkstra, L., Poelman, H. (2014). A Harmonised Definition of Cities and Rural Areas: the New Degree of Urbanisation // Regional Working Paper. WP 01/2014, European Commission, p. 14. - http://surl.li/acwbx

Domeova, L., Jindrova, A. (2014). Quality of Life in the Rural Territories. Agrarian Perspectives XXIII // The Community-Led Rural Development Proceedings of the 23th International Scientific Conference, Prague, Czech University of Life Sciences Prague, p. 47.

Altman, M. (2015). Cooperative Organizations as an Engine of Equitable Rural Economic Development // Journal of Co-operative Organization and Management. Vol. 3(1), pp. 14-23. - https://doi.org/10.1016/j.jcom.2015.02.001

Rodney, H. (2020). Top U.S. Credit Union Regulator Calls Financial Inclusion the "Civil Rights Issue of Our Time". The World Council. - http://surl.li/aaybt [2021 02 04].

Lutsiv, B. (2018). FinTex v systemi finansovoi inkliuzyvnosti [FinTeh in the financial system of inclusiveness] // Svit finansiv. No 4 (57): 110-120. - http://surl.li/aaybw

Zinchuk, T., Kutsmus, N., Kovalchuk, O., Charucka, O. (2018). Challenges of sustainable development of rural economy // Management Theory and Studies for Rural Business and Infrastructure Development. Vol. 40. No. 4: 609619. - http://doi.org/10.15544/mts.2018.53

Dudynets, L., Vernei, O. (2018). Finansova inkliuzyvnist ta yii determinanty [Financial inclusion and its determinants] // Ekonomika ta upravlinnia natsionalnym hospodarstvom. Vol. 130 (2): 8-13. http://ird.gov.ua/sep/sep20182(130)/sep20182(130)_008_DudynetsL,VerneiO.pdf.

Shapoval, Yu. I., Yukhta, O. I. (2019). Vymiriuvannia finansovoi inkliuzii: perevahy ta obmezhennia isnuiuchykh pidkhodiv [Measuring financial inclusion: advantages and limitations of existing approaches] // Ukrainskyi sotsium. No 3 (70): 78-91. - http://surl.li/aaybz

Abramova, I. V. (2020). Stan i priorytety finansovoi inkliuzii v Ukraini [Status and Priorities of Financial Inclusion in Ukraine] // Biznes Inform. No. 10: 294-300. - https://doi.org/10.32983/2222-4459-2020-10-294-300.

Borodina, O., Prokopa, I., Kyryziuk, S., Yarovyi, V. (2020). Fond rozvytku silskykh terytorii yak finansovyi instrument prostorovoi spravedlyvosti v zemlekorystuvanni ta stalomu silskomu rozvytku [Rural Areas Development Fund as a Financial Instrument for Spatial Justice in Land Use and Sustainable Rural Development] // Accounting and Finance. Issue 3, pages 122-130. - https://ideas.repec.org/a/iaf/journl/y2020i3p122-130.html

Dema, D., Abramova, I., Nedilska, L. (2019). Financial and economic conditions of rural development in Ukraine // Eastern Journal of European Studies. Vol. 10. No. 1: 199-220.

USAID (2017). Mizhnarodni partnerstva zarady stabilnosti finansovoho sektoru [International partnerships for the stability of the financial sector]. - https://old.bank.gov.ua/doccatalog/document?id=83136332 [2021 0102 ].

Natsionalnyi bank Ukrainy (2021). Stratehiia rozvytku finansovoho sektoru Ukrainy do 2025 roku [Strategy for the development of the financial sector of Ukraine until 2025]. - https://bank.gov.ua/ua/files/eMbmHjDsYNINdsE [2021 12 03].

Zvit Natsionalnoi komisii, shcho zdiisniuie derzhavne rehuliuvannia u sferi zviazku ta informatyzatsii za $2019 \mathrm{r}$. [Report of the National Commission for the State Regulation of Communications and Informatization for 2019]. http://surl.li/aayby [2021 1504$]$. 